\title{
THE DEVELOPMENT OF RUDIMENTARY METAPODIAL AND ACROPODIAL SKELETONS IN THE SHEEP
}

\author{
H. ČERNÝ and L. BRANDSTÄTTER \\ Department of Veterinary Anatomy, Histology and Embryology \\ University of Veterinary Science, 61242 Brno \\ Received February 22, 1989
}

\begin{abstract}
Černý H., L. Brandstätter: The Development of Rudimentary Metapodial and Acropodial Skeletons in the Sheep. Acta vet. Brno, 1990:3-11.

On the material obtained from six embryos (CRL 18-35 mm), 48 foetuses CRL $70-280 \mathrm{~mm}$ ) and 12 sheep (14 days -15 months) we investigated the development of the rudimentary skeleton of the metapodium and acropodium in tissue sections using light microscopy.

The sections were stained with hematoxylin and eosin, according to van Gieson, with alcian blue and a mixture of Ponceau $2 \mathrm{~K}$ and acid fuchsin. Mineralization during ossification was ascertained by a histochemical calcium examination according to Kossa. The material from the postnatal period was processed by osteological and radiographical methods.

The change of the mesenchymal skeleton of the second an fifth primordia of the metapodium into cartilaginous skeleton in the sheep occurs in its late embryonal stage. In this period, the metapodial skeleton becomes clearly differentiated into the main and the rudimentary skeletons, the cartilaginous skeleton of the lateral primordium becoming markedly reduced in comparison with the axial ones.

The mesenchymal skeleton of lateral primordia is not subject to a change into embryonal cartilage in its full extent. It morphologically differentiates into the proximal skeleton of the second and fifth metapodials and the distal skeleton of the acropodial. The two skeletons are connected by an original mesenchymal blastema. In the course of the development, the metapodial skeleton ossifies, the development of rudimentary skeletons of the second and fifth digits ceases when it reaches the cartilaginous tage.

Ossification of the second and fifth metapodials begins on the 50th day of prenatal development in the foetus of CRL $90 \mathrm{~mm}$, i. e. about 7 days later than ossification of the main skeleton, and corresponds to the diaphyseal ossification of the long bone.

Calcium distribution showed predominance of the resorption phase over the osteogenous phase during ossification. As a result, distal segments of the skeleton are completely resorbed and only their proximal segments are preserved in the postnatal period. The rudiment of the fifth metacarpal is a needle-shaped bone with a head, whose length varies greatly from case to case. It forms a syndesmotic connection with the fourth metacarpal. The second metacarpal is often missing or appears only as a tiny rudiment synostotically connected to the base of the third metacarpal. Rudiments of the second and fifth metacarpals cannot be demonstrated in the definitive skeleton, because they have been fully resorbed.

The one- or two-phalanx skeleton of the acropodium is a cartilaginous cylinder. Proximally, it extends as far as the base of proximal sesamoid bones, while distally it reaches connective structures of the differentiating subcutis. It never ossifies, its development being terminated in the stage of cartilaginous skeleton, which is completely replaced by connective tissue already during the prenatal development.
\end{abstract}

Sheep, prenatal osteogenesis, metapodial ossification, development of the acropodium, rudimentary skeleton, os metacarpale II et $V$. 
Phylogenetic adaptation of Artiodactyla results in an adaptation of their appendicular skeleton, consisting in a symphysis of some of the basipodial bones, symphysis of the main metapodial bones, in the development of the skeleton of the third and fourth digits and a reduction of the skeleton of the second and fourth metapodial and acropodial.

It is therefore possible to divide metapodial and acropodial skeleton in the sheep into the main and rudimentary ones. The rudimentary skeleton belongs among inconstant structures of the definitive skeleton which are subject to regression even during their prenatal ontogenesis. Either they ossify only partly or their development is halted on the level of cartilaginous skeleton. Prenatal development of the skeleton in the sheep has been studied by a large number of authors, who gave a detailed description of individual developmental stages of the foetal skeleton in relation to ontogenetic development. Using various methods from radiography to differential staining in toto and the study of tissue sections, objective results were obtained and published by White (1925), Harris (1937), Green (1946), Benzie (1950), Smith (1956, 1969), Lascelles (1958), Rajtová (1972, 1973), Neiss (1982) and Černý (1987).

An analysis of literary data shows that opinions on the manner and degree of regression of rudimentary skeletal structures are not always unanimous, they often differ, or are based on facts which may require further confirmation.

The aim of this work was to study changes in the morphological picture of the basis of the rudimentary skeleton in prenatal ontogeny as well as morphology of postnatal rudiments.

\section{Materials and Methods}

The development of the second and fifth primordia of the metapodial and acropodial into bone or connective tissue was studied in a total of six sheep embryos (CRL $18-35 \mathrm{~mm}$ ), 48 sheep foetuses (CRL $40-300 \mathrm{~mm}$ ) and 12 Merino sheep 14 days to 15 months old.

The embryonal and foetal material was fixed in $10 \%$ formol and processed in a standard manner for light microscopy. Frontal and horizontal sections made of tissue paraffin or celoidin blocks were stained with' hematoxylin and eosin, according to van Gieson's method, with alcian blue and a mixture of Ponceau $2 \mathrm{~K}$ and acid fuchsin.

Mineralization was assessed by histological demonstration of calcium, using a method according to Kossa.

The material from postnatal period was processed by osteological and radiological methods using Medix Rapid MA films, which were adjusted for rtg-cassettes with sharpness enhancing sheet. Radiograms were recorded on Chiralux 2 at $40 \mathrm{kV}, 18 \mathrm{mAS}$ and $0.24 \mathrm{~S}$, in the dorsopalmar and lateromedial projections.

\section{Results}

In embryos of CRL $18 \mathrm{~mm}$, hand and foot plates were discernible with palmar and plantar surfaces slightly concave. At the edge of the plates, tiny denticles are discernible, separated by shallow notches which are an external indication of the borderline between individual primordia. The primordia form mesenchymal cellular blastema, which already in this period is clearly differentiated between the main and the lateral reduced primordia. In between the primordia, we can observe a reduction of the mesenchyma and formation of blood vessels. In the embryo of CRL $25 \mathrm{~mm}$, a change of the mesenchymal skeleton of the primordium into embryonal cartilage is taking place. With a small delay, a gradual change of the prechondral into chondral blastema is taking place in the foot plate.

Chondrogenesis continues further, with the mesenchymal basis of the main 
primordium being completely replaced by embryonal cartilage in embryos of CRL $35 \mathrm{~mm}$. The external shape of the plate is affected, too: a marked, deep axial notch forms between the skeletons of digits III and IV, and the plate grows longer. The development of the skeleton of the main primordium takes place; primordia II and V are in this stage of prenatal osteogenesis incomparably smaller. Besides, the mesenchyma in the rudiments is changed into embryonal cartilage. It clearly follows from the above that in comparison with the development of the main skeleton the process of chondrogenesis is delayed.

Rudimentary skeletons are formed by cartilaginous cylinders which extend distally to the location of future epiphysodiaphysary boundary of the third and fourth metapodials.

The proximal end of the cartilaginous cylinder of the fifth metapodial is separated from the basis of the fourth metapodial by a layer of connective tissue with a meshwork of blood vessels. As a rule, the basis of the second metacarpal is proximally fused with the cartilaginous basis of the third metacarpal, forming a single whole. Osteological findings on definitive skeletons of adult individuals are in correspondence with this arrangement. Remnants of the second and third metacarpals can be fused with the main skeleton in two different ways - synostotically of syndesmotically.

Rudiments of the fifth metacarpal form exclusively syndesmotic unions, the second metacarpal is often absent or ossifies as a tiny rudiment together with the skeleton of the third metacarpal.

On the pelvic metapodial, proximal ends of all four metapodial skeletons are interconnected to form a single whole, basis metatarsi, and consequently rudiments of the second and fifth metatarsals cannot be demonstrated on the definitive skeleton.

The cartilaginous skeleton of the second and fifth metacarpals ossifies as a rule on the 50th day of development when the foetus CR length is $90 \mathrm{~mm}$, i. e. about 7 days later than the skeletons of the third and fourth metapodials. In the same period, ossification of the skeleton of the second and fifth metatarsals is taking place.

Ossification of the rudimentary cartilaginous skeleton of the second and fifth metapodials corresponds to the diaphyseal ossification of the long bone. It starts in the middle part of the cartilaginous skeleton with perichondrial ossification and progresses in the proximal and distal directions.

Due to the osteogenous activity of perichondrial cells which are gradually differentiated into osteoblasts, a cortical bone lamella is being produced in the form of an incomplete diaphyseal collar.

The topographical distribution of calcium demonstrated histochemically has shown that the cortical lamella is extended by the apposition of newly formed bone tissue, primarily on the medial and dorsal ends, while the lateropalmar end is incomplete and subject to increased resorption even at the beginning of ossification. Together with perichondrial ossification, endochondral ossification and formation of incomplete bone beams are taking place in the hypertrophic cartilage.

Endochondral ossification of the rudimentary skeleton start at the medial end of the diaphysis and gradually progresses in the lateral direction.

A general view shows predominance of the resorption phase over the osteogenous phase in the ossification of the second and fifth metacarpals. As a result, distal segments of the skeletons are completely resorbed. If they remain as bone rudiments until the postnatal period, it is their proximal parts that have survived. 

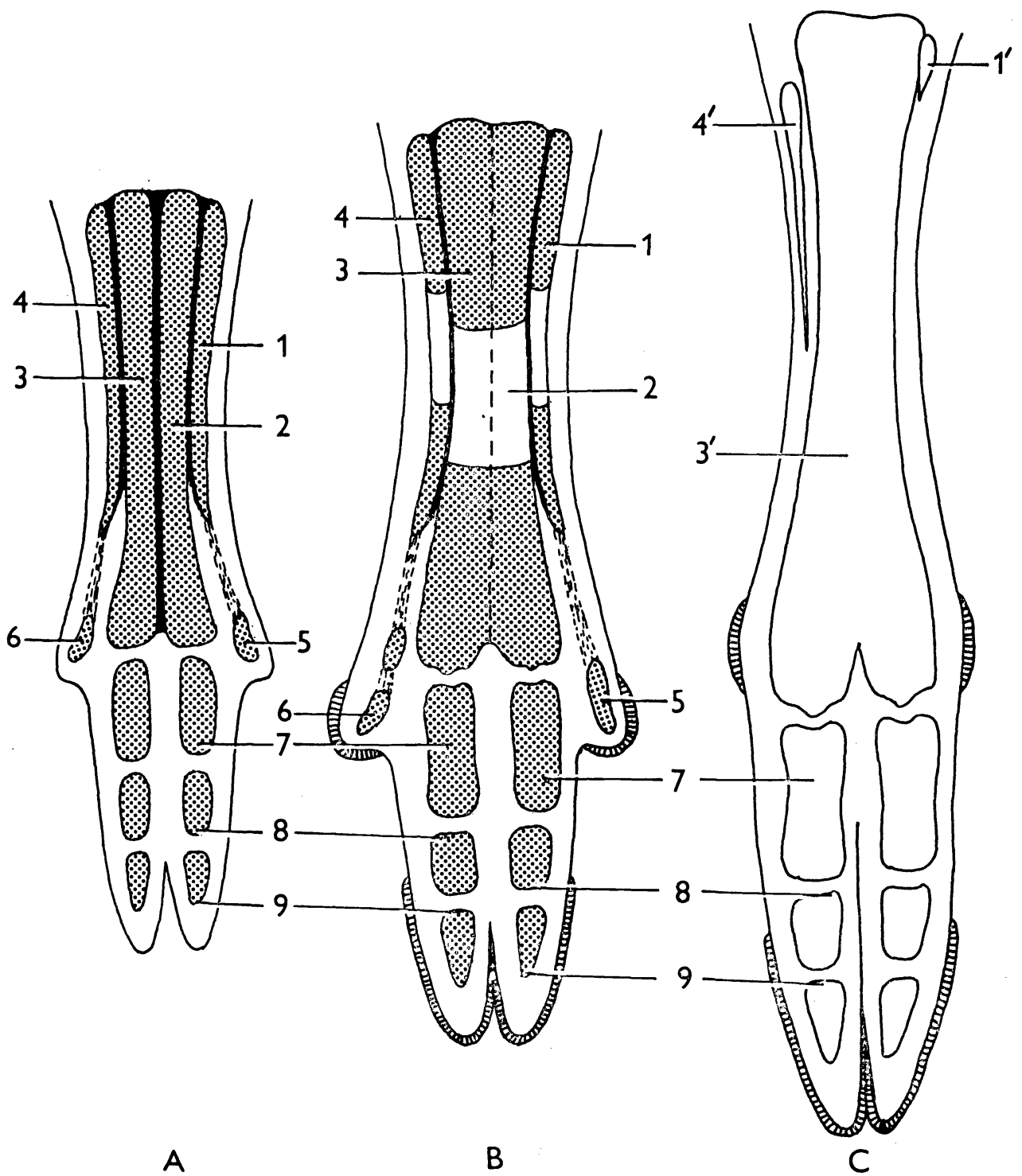

A

B

Diagram: Development of rudimentary skeleton of the sheep forelimb in the stage of cartilaginous skeleton (A), during ossification (B) and definitive bone rudiments in an adult individual (C).

1 - skeleton of the second metacarpal, $1^{\prime}$ - os metacarpale II, 2 - skeleton of the third metacarpal, 3 - skeleton of the fourth metacarpal, $3^{\prime}$ - metacarpus (ossa metacarpalia III et IV), 4 - skeleton of the fifth metacarpal, 4' - os metacarpale V, 5 - skeleton of the 2nd digit, 6 skeleton of the 5 th digit, 7 phalanx proximalis, 8 - phalanx media, $9-$ phalan $\mathrm{x}$ distalis

Os metacarpale $\mathrm{V}$ is a thin needle-like bone located in the surrounding connective tissue at the edge of the fourth metacarpal and joined with it by connective tissue. Its length varies, from a tiny rudiment at the base to a long needle-shaped bone, which reaches as far as half the length of the main metacarpal. It extends 
proximally to form a distinct head with a tiny primary bone cavity in its centre. Os metacarpale II occurs as a tiny rudiment which is synostotically connected with the third metacarpal. Compared with the fifth metacarpal, the second metacarpal occurs less frequently. The skeleton of the second and fifth metatarsals is subjet to a total resorption in the course of the prenatal development.

Topographically, the rudimentary skeleton of the second and fifth digits, which distally penetrate into connective structures of the rudimentary digit, is located abaxially from the skeleton of proximal abaxial sesamoid bones. They occur as a one- or two-phalanx cartilaginous skeletons, which are proximally connected with the distal end of the rudimentary metacarpal skeleton by means of a mesenchymal band. The cartilaginous skeleton of the acropodium never ossifies, its development ceases at the stage of cartilage, which is replaced by connective tissue during prenatal development. We observed the change of cartilage into connective tissue in a foetus of CRL $280 \mathrm{~mm}$ at the age of 100 days post copulationem.

Osteological and radiological examinations of the definitive skeleton showed that skeletal rudiments of the second and fifth digits in the sheep could not be demonstrated postnatally.

Plates I. to X. are at the end of the volume.

\section{Discussion}

The study of the development and morphology of vestigial structures in ontogenesis presents a very interesting and varied picture. Already in the embryonal stage of the sheep development, in the period of the mesenchymal skeleton, we find that prechondral lateral primordia of the second and fifth metapodials are markedly thinner compared with axial primordia. The next period of structural differentiation is characterized by a change of the mesenchymal skeleton into the cartilaginous embryonal skeleton. Studying the chondrogenesis of the skeleton of the second and fifth metacarpals we found that the mesenchymal skeleton is not fully replaced with embryonal cartilage. It is clearly divided into proximal cartilaginous skeleton of the metapodium and the distal cartilaginous skeleton of the acropodium. The two cartilaginous skeletons are connected with the original mesenchymal blastema in the epiphyseal region of the third and fourth metacarpals.

The basic questions is the reduction mechanism of rudimentary skeletons of the second and fifth metacarpals and metatarsals. Earlier authors like Rosenberg (1873) or Harris (1937) believed that the reduction of the second or fifth metapodials takes place on the level of the cartilaginous skeleton. Harris (1937) also supposed that skeletons of the second and fifth metacarpals were incorporated into the main metacarpal bones in the period of their growth.

In agreement with Smith (1956), Rajtová $(1972,1973)$ and Neis s (1982), our findings show that the cartilaginous skeletons of the second and fifth metacarpals and metatarsal are subject to ossification.

Different data are found in connection with the onset of ossification of the metapodial skeleton. Harris (1937) and Lascelles (1959) stated that the onset of ossification of metapodial diaphyses can be observed on the 46th day of foetal age, Rajtová $(1972,1973)$ on the 38th day, Černý (1987) on 43rd day and Benzie (1950) on the 60th day. As regards ossification of cartilaginous skeleton of the second and fifth metacarpals, we observed a week's delay in comparison 
with the third and fourth metacarpals, i. e. ossification occurred on approximately the 50th day of foetal age.

In practically the same period, ossification of the skeleton of the second and fifth metatarsals begins but in this case cartilaginous rudiments are not separated but form a single whole at the base. It is definitely not a case of a fusion of individual metapodials, as interpreted by Harris (1937). Ossification need not always be accompanied by mineralization of the second metatarsal, as observed by Neiss (1982).

Histochemical examination demonstrated the distribution of calcium associated with the mineralization of the ossifying cartilage. Similarly as in the ossification of the main skeleton, ossification of the second and fifth metapodials begins with periosteal activity in the medial section of the diaphysis and the formation of a superficial diaphyseal collar formed by a cortical bone lamella. The process of perichondrial ossification begins medially, along the axis of the limbs, and progresses laterally. This fact was mentioned without any detailed explanation by Rosenberg (1873) and our finding also confirms a similar statement by Neiss (1982). Calcium deposition in the tissue can be explained by local changes with related biological requirements, perhaps even by mechanical stimuli at the projection of the axis of the limb from which the process progress laterally and affects the skeleton of the second and fifth metapodials.

In the ossification of the second and fifth metapodials, predominance of the resorption phase over the osteoblastic phase is readily discernible. The cortical lamella is usually incomplete at its lateropalmar edge, beams are resorbed, intertrabecular space is enlarged and the bone is continuously replaced by connective tissue.

The distal segment of the original primordium, representing the basis of the rudimentary skeleton of the second and fifth digits, undergoes a slightly different development. Rajtová (1972) states that ossification of the rudimentary second and fifth digits in the sheep begins on the 90th day of prenatal development. Ossification points are not necessarily formed constantly in all foetuses and the author goes on to say that in many cases ossification takes place only after birth. The one- and rarely two-phalanx cartilaginous skeletons of the second and the fifth digits are not subject to ossification. In the prenatal stage the cartilage was already replaced by connective tissue intermeshed with blood capillaries, which play a major role in the breakdown of the cartilage and its replacement with connective tissue.

The prenatal morphogenesis described gives a causal explanation of the fact why the osseous skeleton of the second and fifth digits is missing from the definitive sheep skeleton. The only skeleton of epidermal formations is differentiated subcutis, whose structure changes into a band of connective tissue, which is the only development remnant of the skeleton of the second and fifth digits.

According to Kolda (1936), the osseous rudimentary skeleton in cattle is formed by one or two small irregular bones enclosed in connective tissue and not connected with the main metacarpal bone with a joint. They are connected with connective tissue and if two bones have developed, they are usually separated from each other. The author does not comment upon the corresponding situation in the sheep.

When studying the complex ontogenetic development of rudimentary skeletons of the metapodium and the acropodium, we shall necessarily start looking for causal relations and explanations in phylogenesis. 
Starck (1979) presented a detailed summary of the contemporary knowledge on the devolopment of the skeleton of vertebrates. From the comparative point of view it is interesting to note that in telemetacarpal deer the distal segment of the skeletnn of the second and fifth digits is preserved, while the proximal segment completely disappears. The skeleton of the second and fifth metatarsals also completely disappear. In plesiometacarpal cervids, on the other hand, only proximal segments of the skeleton in the shape of thin needle-like bones are preserved, while distally the skeleton disappears completely.

Similarly in the family Bovidae, the second and fifth metacarpals disappear except some minimum proximal remnants, which are synostotically connected with the main skeleton of the metapodium (Starck 1979).

Our results confirm the irregular occurrence of proximal rudiments of os metacarpale II et III in the sheep.

Osteological findings from postnatal ontogenesis correspond with the morphological picture of the prenatal development. The rudiment of the fifth metacarpal connects with the main skeleton only syndesmotically, the second metacarpal only synostotically. The fifth metacarpal occurs more frequently than the second metacarpal. The shape of the rudiments is not morphologically stabilized, the length of the fifth metacarpal exhibits considerable variability, reaching in some cases distally up to the middle of the main skeleton. This fact, supported also by our findings, was pointed out by White already in 1925 .

Both rudiments are remnants of ossification of the diaphysis of reduced skeletons. This is proved by a finding of a central primary bone cavity in the proximal segment of the fifth metacarpal.

In the pelvic metapodials, all bases are fused in one skeleton - basis metatarsi so that rudiments of the second and fifth metatarsals cannot be demonstrated separately.

Rudimentary, irregularly occurring structures of the definitive skeleton are formed on the basis of insufficient development of their reduced skeletons in the period of prenatal ontogenesis. The amount of reduction as a regressive process of the development determines the size, shape and topography of these structures, whose existence is subject to considerable variations even within one species. This fact was already mentioned by White (1925), Smith (1969) and more recently by Neiss (1982).

\section{Vývoj rudimentárního skeletu metapodia a akropodia u ovce}

Na materiálu získaném ze 6 embryí (TK $18-35 \mathrm{~mm}$ ), 48 fetů (TK $-280 \mathrm{~mm}$ ) a 12 ovci ( 14 dnů - 15 měsíců) jsme sledovali vývoj rudimentárního skeletu metapodia a akropodia na tkáňových řezech $\mathrm{v}$ obraze světelného mikroskopu.

Rezy byly barveny hematoxylin-eosinem, van Giesonem a alcianovou modří a směsí Ponceau $2 \mathrm{~K}$ spolu s kyselým fuchsinem. Mineralizace během osifikace byla sledována histochemickým průkazem kalcia metodou podle Kossy. Materiál z postnatálního období byl zpracován osteologickou a rentgenologickou metodou.

$\mathrm{K}$ přeměně mesenchymového základu II. a V. paprsku metapodia $\mathrm{v}$ chrupavčitý základ dochází u ovce v pozdním embryonálním období. $\mathrm{V}$ tomto období se zřetelně diferencuje skelet metapodia na hlavní a rudimentární, chrupavčité základy postranních paprsků jsou ve srovnání s axiálními zřetelně redukované.

Mesenchymový základ postranních paprskủ nepodléhá v celém rozsahu přemě- 
ně v embryonální chrupavku. Morfologicky se diferencuje na proximální základ II. a V. metapodia a na distální základ akropodia. Oba základy spojuje původní mesenchymový blastém. V průběhu vývoje základ metapodia osifikuje, vývoj rudimentárních základů skeletu II. a V. prstu se ukončuje na úrovni chrupavky.

Osifikace II. a V. metapodia začíná v 50. dnu prenatálního vývoje u fetu TK $90 \mathrm{~mm}$, tzn. asi o 7 dní později než osifikace hlavního skeletu a odpovídá osifikaci diafýzy dlouhé kosti.

Distribuce kalcia ukázala, že $\mathrm{v}$ osifikaci převažuje resorpční fáze nad fází osteogenní. $\mathrm{V}$ důsledku toho jsou distální úseky základů zcela resorbovány a do postnatálního období se dochovávají jen jejich proximální části. Rudiment V. mtc. má podobu jehlicovité kosti s hlavičkou, jejiž délka je značně variabilní, se IV. mts. se spojuje syndesmoticky. II. mtc. často chybí nebo se vyskytuje jako nepatrný rudiment, který se synostoticky spojuje s bází III. mtc. Rudimenty II. a V. mtt. nelze na definitivním skeletu prokázat. Podléhají zcela resorpci a osifikují společně se základy hlavního skeletu v bázi metatarzu.

Jednočlánkový nebo dvoučlánkový základ akropodia má tvar chrupavčitého válečku. Proximálně zasahuje $\mathrm{k}$ základu proximálních sezamských kostí, distálně dosahuje pojivové struktury diferencujícího se podkoží. V žádném př́padě neosifikuje, jeho vývoj končí na úrovni chrupavčitého základu, který je již v průběhu prenatálního vývoje zcela nahrazen vazivovou tkání.

\section{Развитие Рудиментарного скепета метаподия и акроподия овец}

На полученном у 6 эмбрионов (ТК 18 - 34 мм), 48 плодов (ТК 70 280 мм) и 12 овец (14 суток - 15 месяцев) материале проводили исследования развития рудиментарного скелета метаподия и акроподия на тканевых срезах в изображении светового микроскопа.

Срезы красили гематоксилин эозином, красителем ван Гизона, альциановым голубым и смесью Понсо 2К совместно с кислым фуксином. Наблюдения за минерализацией в ходе оссификации проводили посредством гистохимического определения кальция методом по Косса. Материал постнатального периода обрабатывали остеологическим и рентгенологическим методами.

Преобразование мезенхиматозной основы II и V пүчков метаподия в хрящевую основу у овцы происходит в поздний эмбриональный период. В упомянутый период наблюдается четкая дифференциация скелета метаподия в главные, рудиментарные, хрящеватые основы посторонних пучков по сравнению с аксиальными явно редуцированы.

Мезенхиматозная основа посторонних пучков не меняется полностью в эмбриональный хрящ. Морфологически она делится на проксимальную основу II и V метаподиев и на дистальную основу акроподия. Обе основы соединяет первоначальный мезенхимальный бластем. В дальнейшем развитии основание метаподия оссифицирует, развитие рудиментарных оснований скелета II и V пальцев завершается на уровне хряща.

Оссификация II и V метаподиев начинается 50 сутки предродового развития плода TK 90 мм, следовательно, приблизительно на 7 суток позже оссификации главного скелета и она соответствует оссификации диафиза длинной кости. 
Распределение кальция свидетельствует о том, что в оссификации преобладающей является фаза резорбции по сравнению с остеогенной фазой. В результате этого дистальные участки оснований полностью резорбированы и до послеродового периода сохраняются проксимальные части. Рудимент У пальца имеет форму игольчатой кости с головкой, длина которой существенно меняется, c IV метакарпальной костью он соединяется синдесмотически. II кость зачастүю отсүтствует или встречается в форме незначительного рудимента, синостотически соединенного с основой III метакарпальной кости. Рудименты II. и V. метатарза на окончательном скелете нельзя установить. Они полностью подвержены резорбции и оссифицируют совместно с основой главного скелета на базе метатарза.

Однофаланговое или двухфаланговое основание акроподия имеет форму хрящеватого валика. Проксимально он затрагивает основание проксимальных сезамовидных костей, дистально достигает соединительнотканной структуры дифференцирующегося подкожного слоя. Ни в коем случае он не оссифицирует, его развитие завершается на уровне хрящеватого основания, замененного полностью уже в предродовой период соединительной тканью.

Our thanks are due to members of the laboratory staff of our department, Alena Hloušková and Renata Spěšná, for their technical assistance and in particular for preparation of histological material, and to Jana Ludviková for her help in documenting the results.

\section{References}

BENZIE, D.: Growth of the skeleton of the foetal sheep. Brit. Vet. J,. 106, 1950: 231-234

ČERNÝ, H.: Ossifizierung des Meta- und Akropodiums im Laufe der frühen fötalen Ontogenese beim Schaf. Schweiz. Arch. Tierheilk., 129, 1987: 389-397

EVANS, H. E., SACK, W. O.: Prenatal Development of Domestic and Laboratory Mammals. Anat., Histol., Embryol., 2, 1973: $11-45$

GREEN, W. W.: Comparative growth of the sheep and bovine animal during prenatal life. Am. J. Vet. Res., 7, 1946: 395-402

HARRIS, H.: The foetal growth of sheep. J. Anat., 71, 1937, 516-527

KOLDA, J.: Srovnávací anatomie zvírat domácích. II. Nauka o kostech a chrupavkách. Novina, Brno, 1936: $914 \mathrm{p}$.

LASCELLES, A. K.: The time of appearance of ossification in the Peppin-type Merino. August. J. Zool., 7, 1959: 79-86

NEISS, W. F.: Zur Ossification des Schafskelettes. Gegenbaurs Morph. Jahrb., 128, 1982: 41-57

RAJTOVÁ, V.: Über die Entwicklung des Skelets bei Schaf und Ziege. I. Osteogenesis der Vorderextremität. Gegenbaurs. Morph. Jahrb., 118, 1972 b: 577-588

RAJTOVÁ, V.: Über die Entwicklung des Skelets bei Schaf und Ziege. II. Osteogenesis der Hinterextremität. Gegenbaurs. Morph. Jahrb., 119, 1973: 76-85

ROSENBERG, A.: Über die Entwicklung des Extremitätenskelettes bei einigen durch Reduction ihren Gliedmassen charakteristischen Wirbeltieren. Z. Wiss. Zool., 23, 1873: 116-168

SMITH, R. N.: A survey of the incidence of the second and fifth metacarpals and metatarsals in the sheep. Brit. Vet. J., 112, 1956 b: 175-177

SMITH, R. N.: Transient elements of the sheep skeleton. Brit. Vet. J., 116, 1960: 276-280

STARCK, D.: Vergleichende Anatomie der Wirbeltiere auf evolutionsbiologischer Grundlage. Band 2: Das Skeletsystem. Springer Verlag, Berlin, Heidelberg, New York, 1979: $776 \mathrm{p}$.

WHITE, P.: Note on the vestigial metacarpals of the sheep. Brit. Vet. J., 81, 1925: 231-233 
Černý H. and Brandstätter L.: The Development of Rudimentary... Legends to Plates I. to X.

Plate I.

Fig. 1: Longitudinal section of the foot plate 1-2nd primordium, 2-3rd primordium, 3-4th primordium, $4-5$ th primordium, 5 - reduced mesenchyma with blood vessels in intradigital groove

Embryo, CRL $18 \mathrm{~mm}$, HE, magnification $3.2 \times 4$

Fig. 2: Cartilaginous skeleton of hand plate digits in embryo of CRL $35 \mathrm{~mm}$

1 - skeleton of the 2nd digit, 2 - skeleton of the 3rd digit, 3 - selekton of the 4th digit, 4 - skeleton of the 5 th digit, 5 - intradigital groove

Embryo, CRL $35 \mathrm{~mm}$, HE, magnification $2.8 \times 4$

Plate II.

Fig. 3: Detailed view of the proximal part of the fith metapodial

1 - cartilaginous skeleton of the fourth metacarpal, 2 - proximal end of the skeleton of the fifth metacarpal, 3 - blood vessel, 4 - connective tissue

Foetus, CRL $90 \mathrm{~mm}$, HE, $10 \times 4$

Fig. 4: Beginning of ossification of the medial segment of the skeleton of the fifth metacarpal

1 - fourth metacarpal, 2 - fifth metacarpal, 3 - blood capillaries penetrating into hypertrophic cartilage, 4 - perichondrium, 5 - skeleton of the fascia, 6 - mesenchymal rudiment of cutis and subcutis, 7 - epidermis

Foetus, CRL $90 \mathrm{~mm}, \mathrm{HE}, 10 \times 4$

Plate III.

Fig. 5: Cross-section of the metapodium

1 - second metapodial, 2 - third metapodial, 3 - fourth metapodial, 4 - fifth metapodial, 5 - skeleton of $\mathrm{m}$. interosseus, 6 - tendon rudiment of the deep flexor muscle of digits, 7 - tendon rudiment of the superficial flexor muscle of digits, 8 - basis of the tendon of the common and lateral extensor muscle of digits (9)

Embryo, CRL $35 \mathrm{~mm}, \mathrm{HE}$, magnification $10 \times 4$

Fig. 6: Cross-section of the basis of os metacarpale $\mathrm{V}$

1 - bone beams of the fourth metacarpal, 2 - compact lamella of the diaphysis, 3 osteogenous blastema of the periost, 4 - periost, 5 - periost of the rudimentary bais of the fifth metacarpal, 6 - diaphyseal lamella of a compact bone, 7 - hypertrophic cartilage, 8 - basis of the $\mathrm{m}$. interosseus, 9 - basis of the deep and superficial fascia (10) Foetus, CRL $150 \mathrm{~mm}, \mathrm{HE}$, magnification $20 \times 4$

Fig. 7: Histochemical ascertainment of calcium distribution (after Kossa)

1 - ossification of the fourth metacarpal, 2 - ossification of the fifth metacarpal, 3 hypertrophic cartilage, 4 - periost, 5 - osseous lamella of a compact bone, 6 - incompact bone, 6 - incomplete diaphyseal collar

Foetus, CRL $200 \mathrm{~mm}$, Kossa, magnification $40 \times 4$

Plate IV.

Fig. 8: Cross-section of the cartilaginous skeleton of the metatarsal

1 - skeleton of the second metacarpal, 2 - skeleton of the third metacarpal, 3 - skeleton of the fourth metacarpal, 4 - skeleton of the fifth metacarpal, 5 - skeleton of $m$. interosseus, 6 - tendon of the deep and superficial flexor muscles (7), 8 - skeleton of os sesamoideum metatarsale

Foetus, CRL $120 \mathrm{~mm}$, HE, magnification $3.2 \times 4$

Fig. 9: Cross-section of the cartilaginous skeleton of the metatarsal

1 - skeleton of the second metacarpal, 2 - skeleton of the third metacarpal, 3 - connective tissue between the two skeletons

Foetus, CRL $120 \mathrm{~mm}$, HE, magnification $10 \times 4$

Fig. 10: Cross-section of the skeleton of the second and third metacarpals of the pelvic limb 1 - skeleton of the second metatarsal, 2 - skeleton of the third metatarsal, 3 - connective tissue

Foetus, CRL $120 \mathrm{~mm}$, HE magnification $6.3 \times 4$

Plate V.

Fig. 11: Differentiation of the cartilaginous skeleton of the 2nd digit

mesenchymal skeleton, 2 - embryonal cartilage, 3 - surrounding mesenchyma, 4 rudimental corium, 5 - epidermis

Foetus, CRL $45 \mathrm{~mm}, \mathrm{HE}$, magnification $10 \times 4$ 
Fig. 12: Cross-section of the rudiment of the 5 th digit 1 - reduced cartilaginous skeleton, 2 - abaxial proximal sesamoid bone, 3 - proximal phalanx of the 3rd digit, 4 - pulvinus digitalis, 5 - epidermis, 6 - skin with hair follicles

Foetus, CRL, $215 \mathrm{~mm}$, HE, magnification $3.2 \times 4$

Plate VI.

Fig. 13: Two-phalanx cartilaginous skeleton of the rudiment digit of the pelvic limb

1 - proximal phalanx, 2 - distal cartilaginous phalanx, 3 - os sesamoideum proximale abaxiale, 4 - skeleton of the third metatarsal, 5 - phalanx proximalis, 6 - epidermis Foetus, CRL $130 \mathrm{~mm}$, HE, magnification $6.3 \times 4$

Fig. 14: Cross-section of the rudiment skeleton of the digit 1 - cartilaginous skeleton subject to reduction, 2 - subcutis differentiating into pulvinus digitalis, 3 - epidermis, 4 - mesenchyma with blood vessels, 6 - densified mesenchymal blastema connecting the acropodial and metapodial skeletons

Foetus, CR $215 \mathrm{~mm}$, alcian blue, magnification $6.3 \times 4$

Plate VII.

Fig. 15: Penetrating blood capillaries with pericapillary mesenchyma

1 - mesenchyma, 2 - blood capillaries, 3 - arranged mesenchyma

Foetus, CR $280 \mathrm{~mm}$, Goldner, magnification $10 \times 4$

Fig. 16: Detailed view of the structure replacing cartilaginous skeleton of digit

1 - mesenchyma differentiating into fibroblasts, 2 - blood capillaries, 3 - arranged mesenchyma

Foetus, CR $280 \mathrm{~mm}$, Goldner, magnification $40 \times 4$

Fig. 17: Replacement of the cartilaginous skeleton of the rudiment of the 5th digit with connective tissue

1 - connective tissue, 2 - blood vessels, 3 - pulvinus digitalis, 4 - arranged connective tissue, 5 - mesenchymal primordium transformed into an arranged zone of the 5th digit Foetus, CR $330 \mathrm{~mm}$, HE, magnification $3.2 \times 4$

Plate VIII.

Figs. 18, 19, 20, 21 : Radiograms of the metacarpal, dorsopalmar projection. Arrow identifies rudiments of os metacarpale $\mathrm{V}$ Magnification $1: 1$

Plate IX.

Figs. 22, 23, 24, 25: Definitive skeleton of ossa metacarpalia II -V

1 - os metacarpale II, 2 - os metacarpale III, 3 - os metacarpale IV, 4 - os metacarpale V

Magnification $1: 1$

Plate X.

Fig. 26: Skeleton of the metacarpal

1 - os metacarpale II, 2 - os metacarpale III, 3 - os metacarpale IV

Magnification $1.5: 1$

Fig. 27: Rudiment of os metacarpale II

1 - os metacyrpale II, 2 - os metacarpale III, 3 - synostotic connection, 4 - apec of the rudiment Magnification $2: 1$

Fig. 28: Morphology of rudimentary os metacarpale $\mathrm{V}$

1 - broadened proximal zone, 2 - corpus, 3 - apex Magnification 1.5: 1 
Plate I.

Cerný H. and Brandstätter L.: The Development of Rudimentary ... Plates I to X.
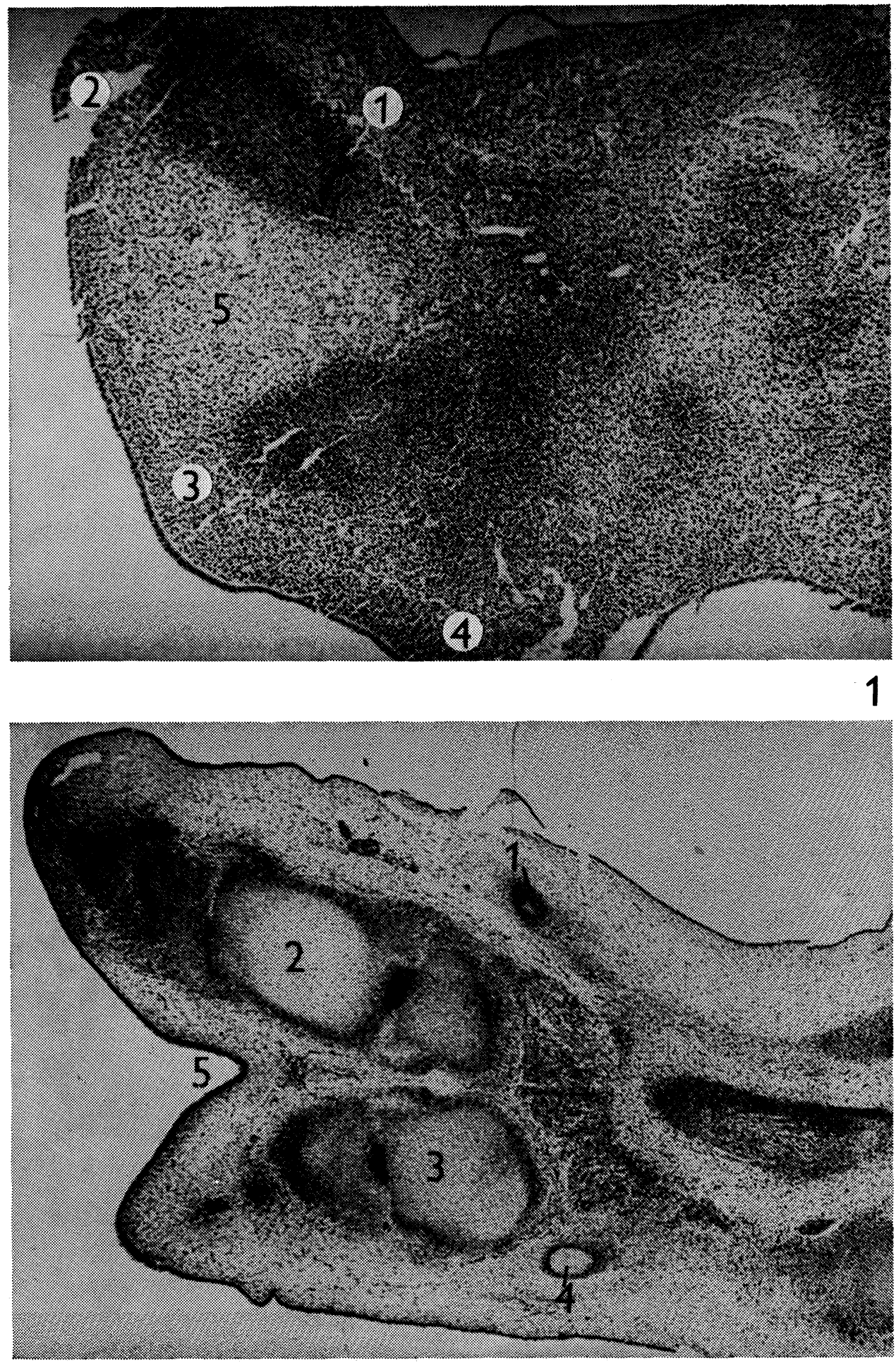
Plate II.

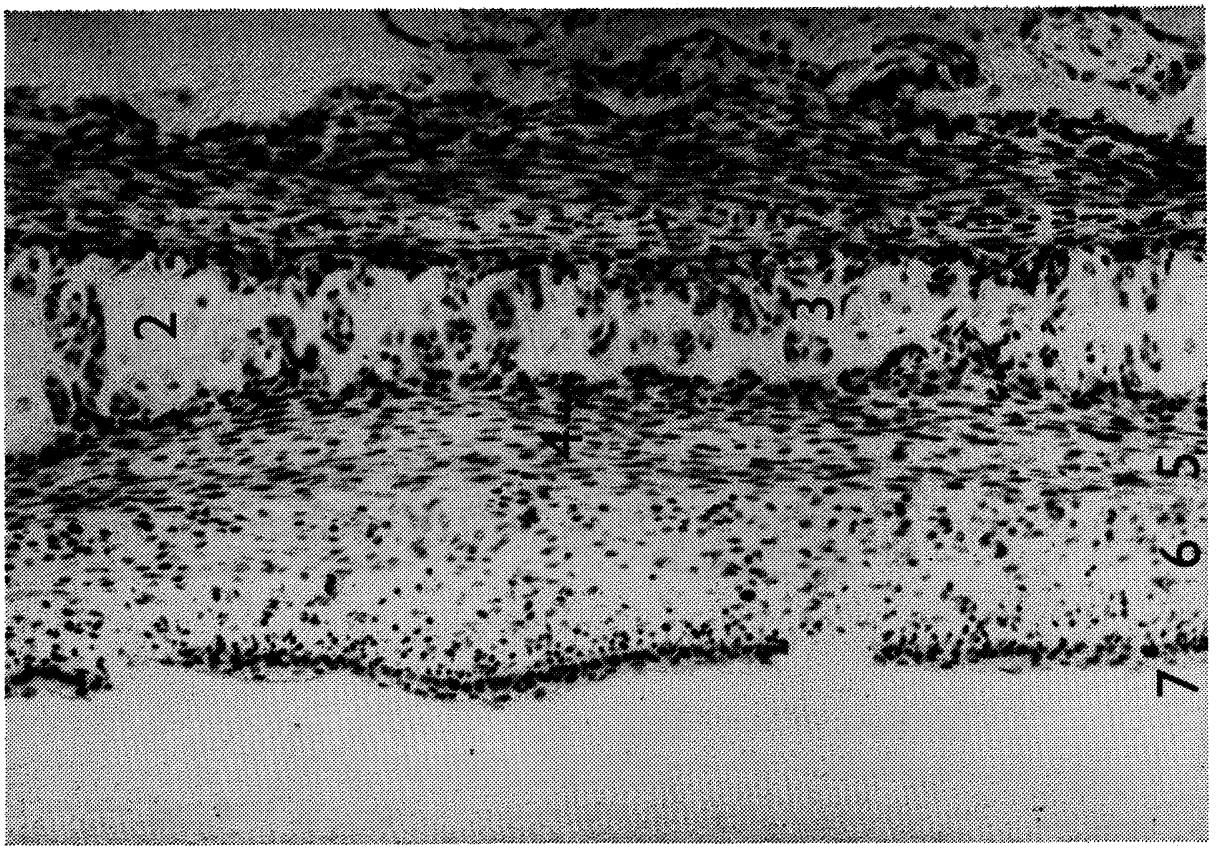

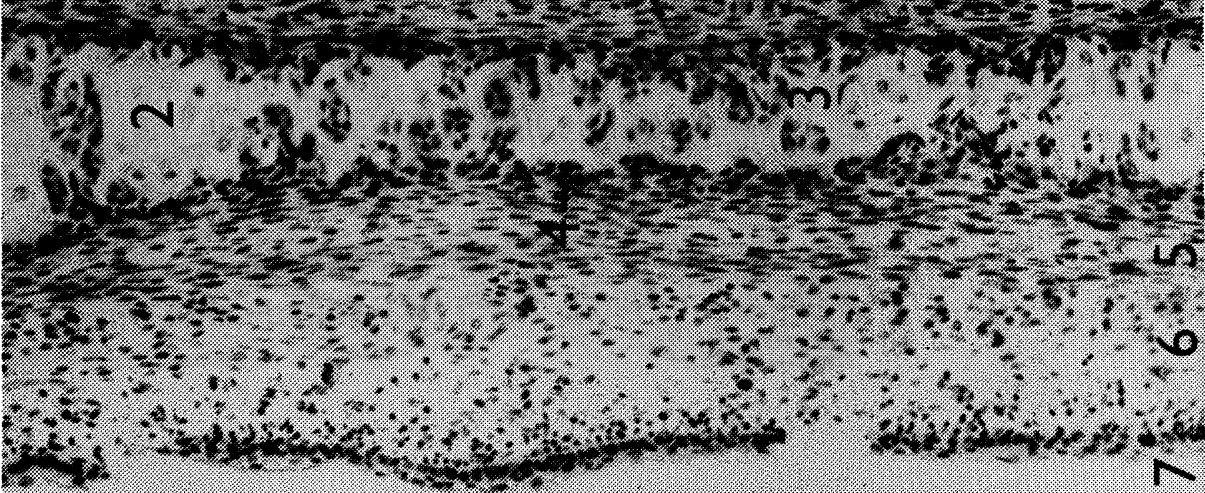

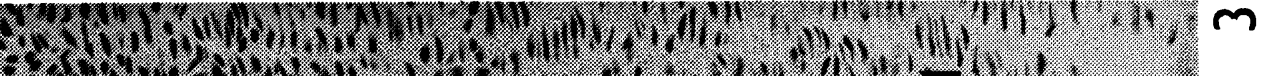

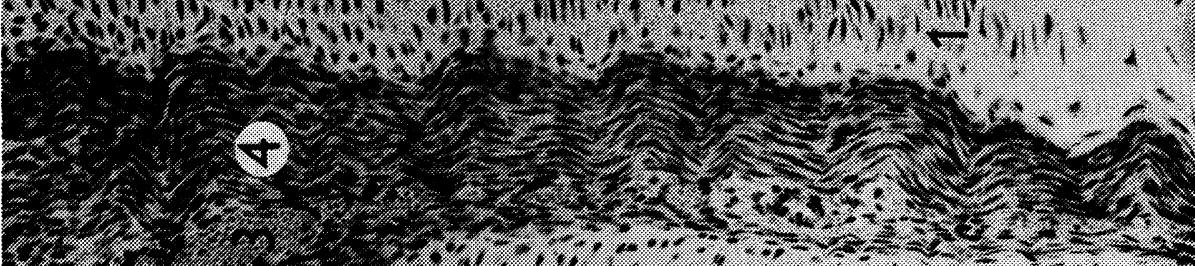
(3) -10
-3 \begin{tabular}{l}
3 \\
\hline
\end{tabular} \begin{tabular}{l}
3 \\
\hline
\end{tabular} 2.

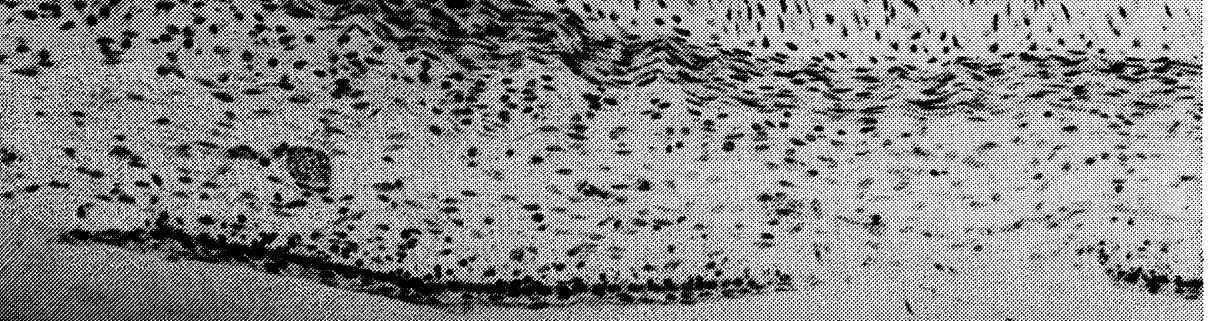



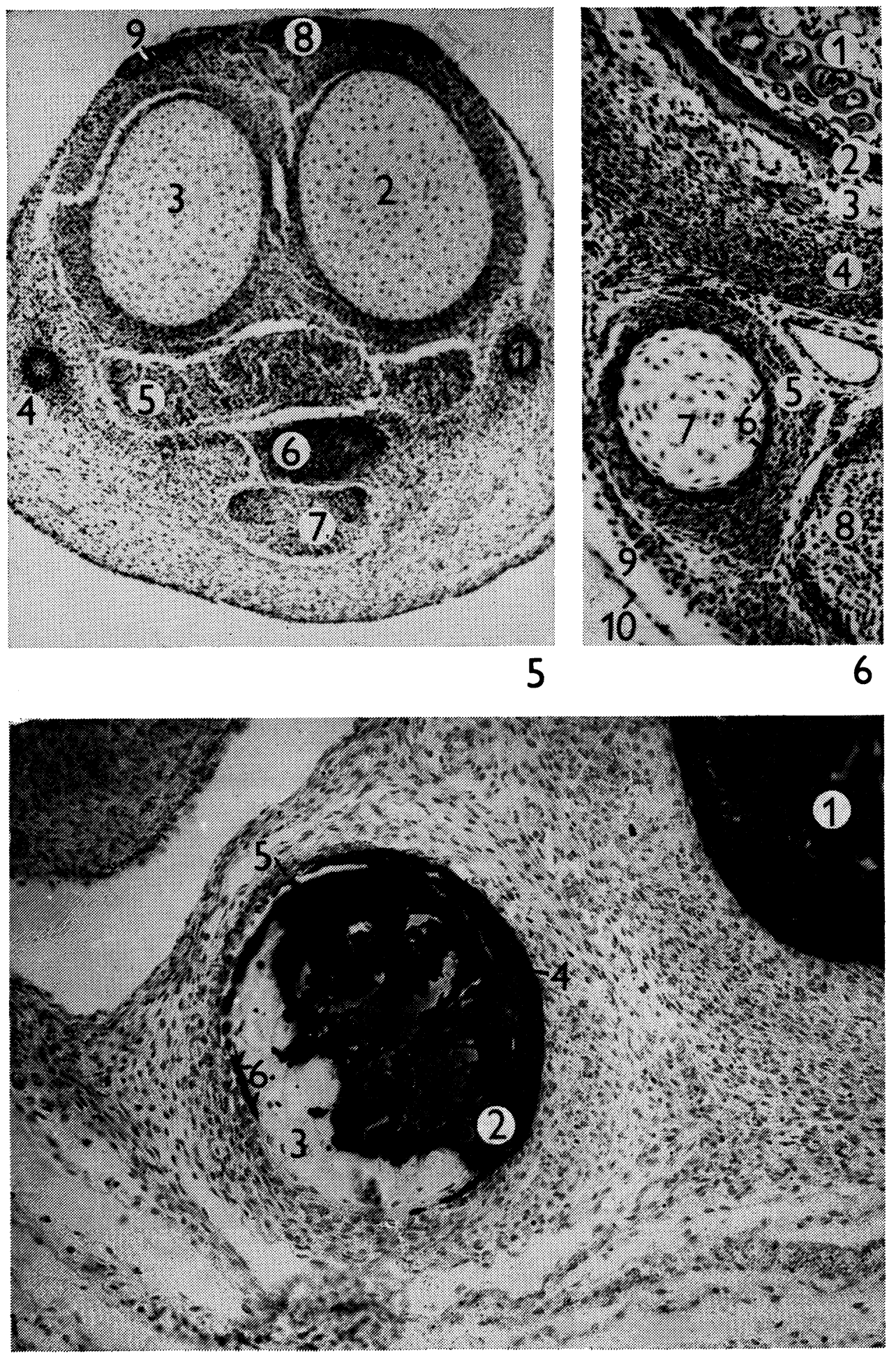
Plate IV.

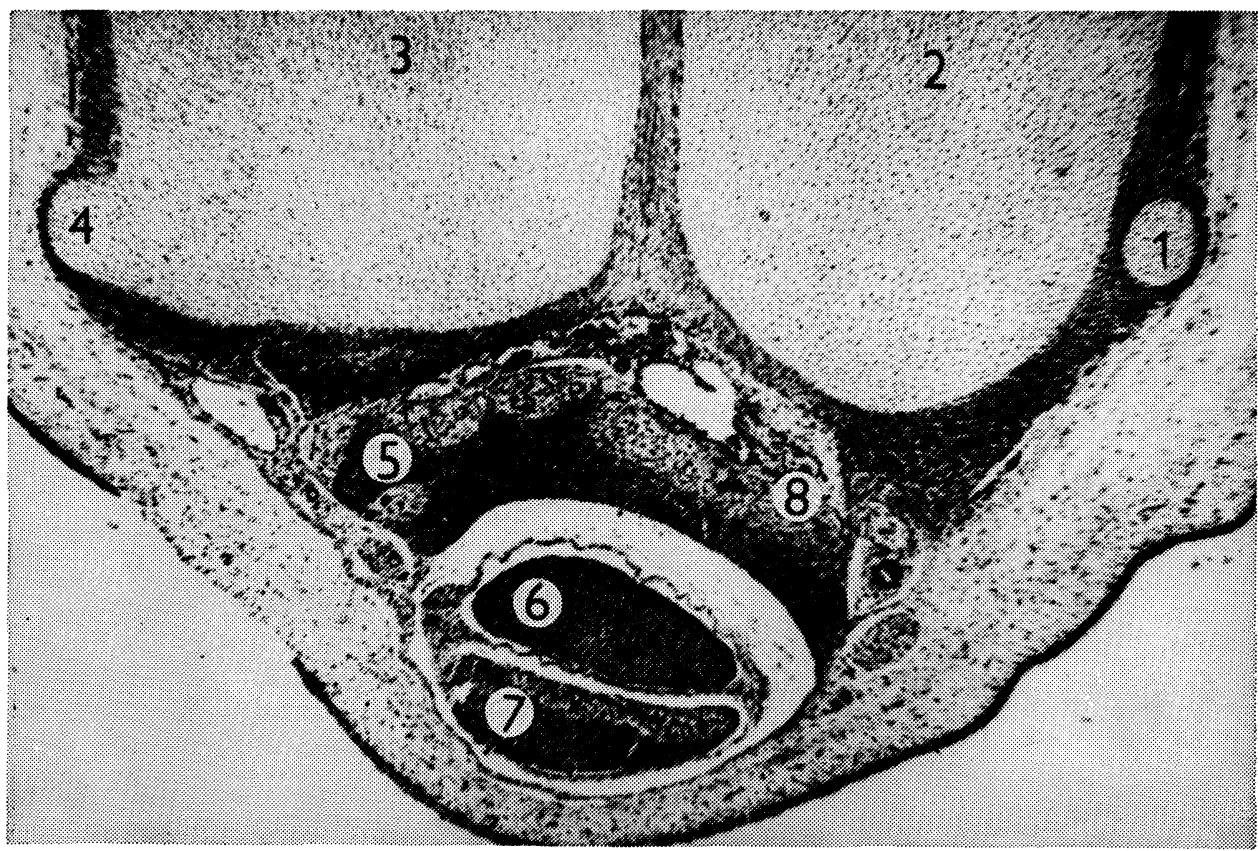

8
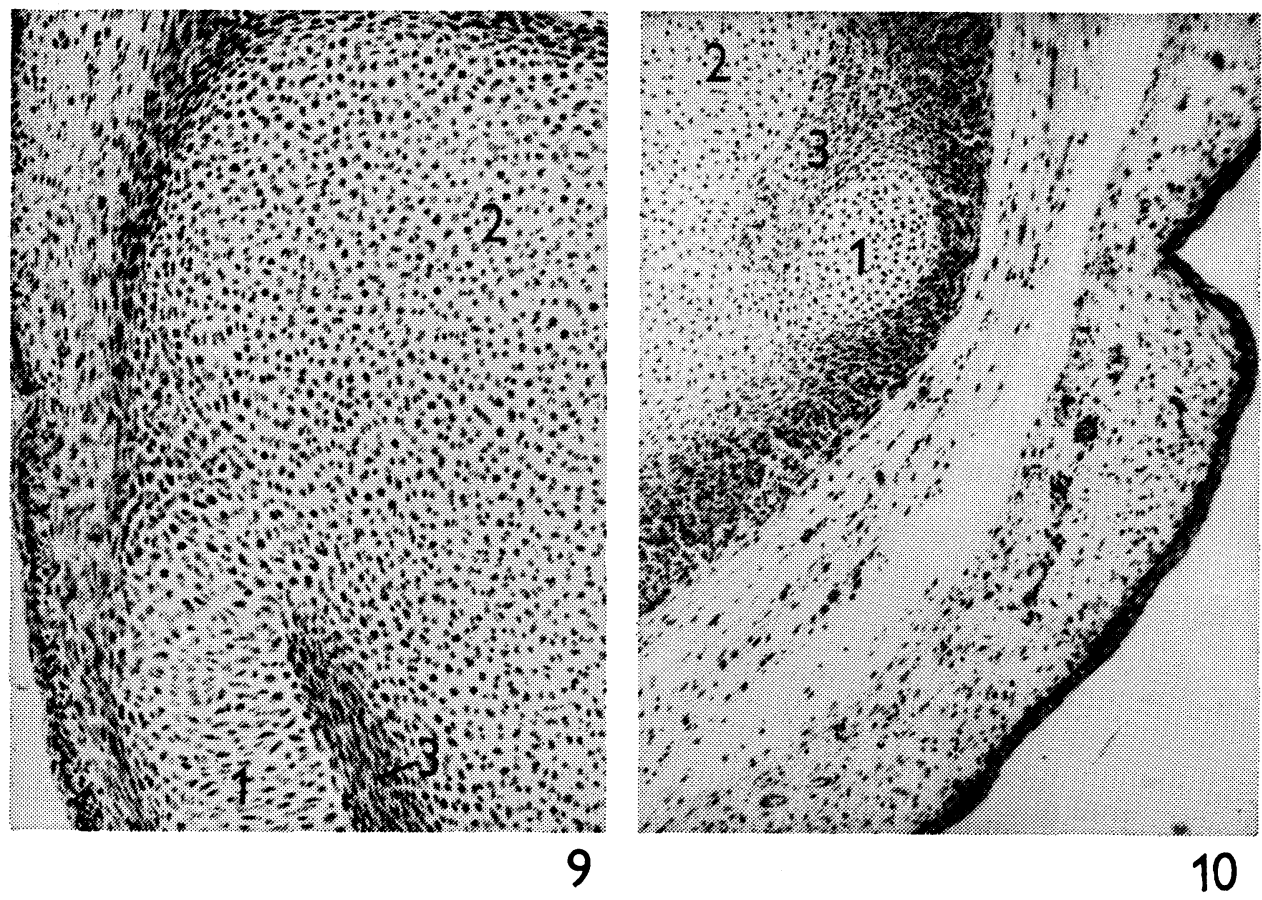


\section{Plate V.}

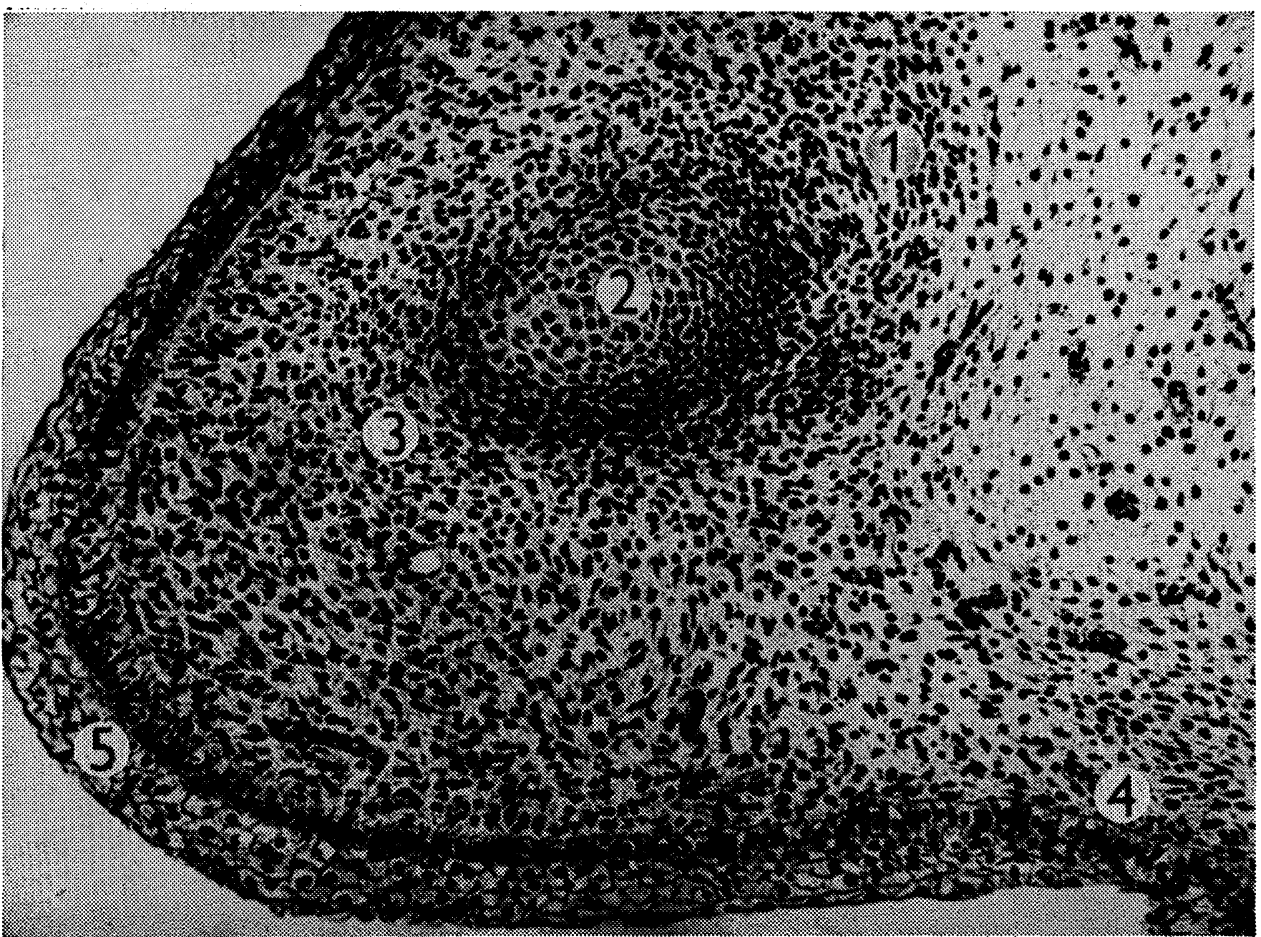

11

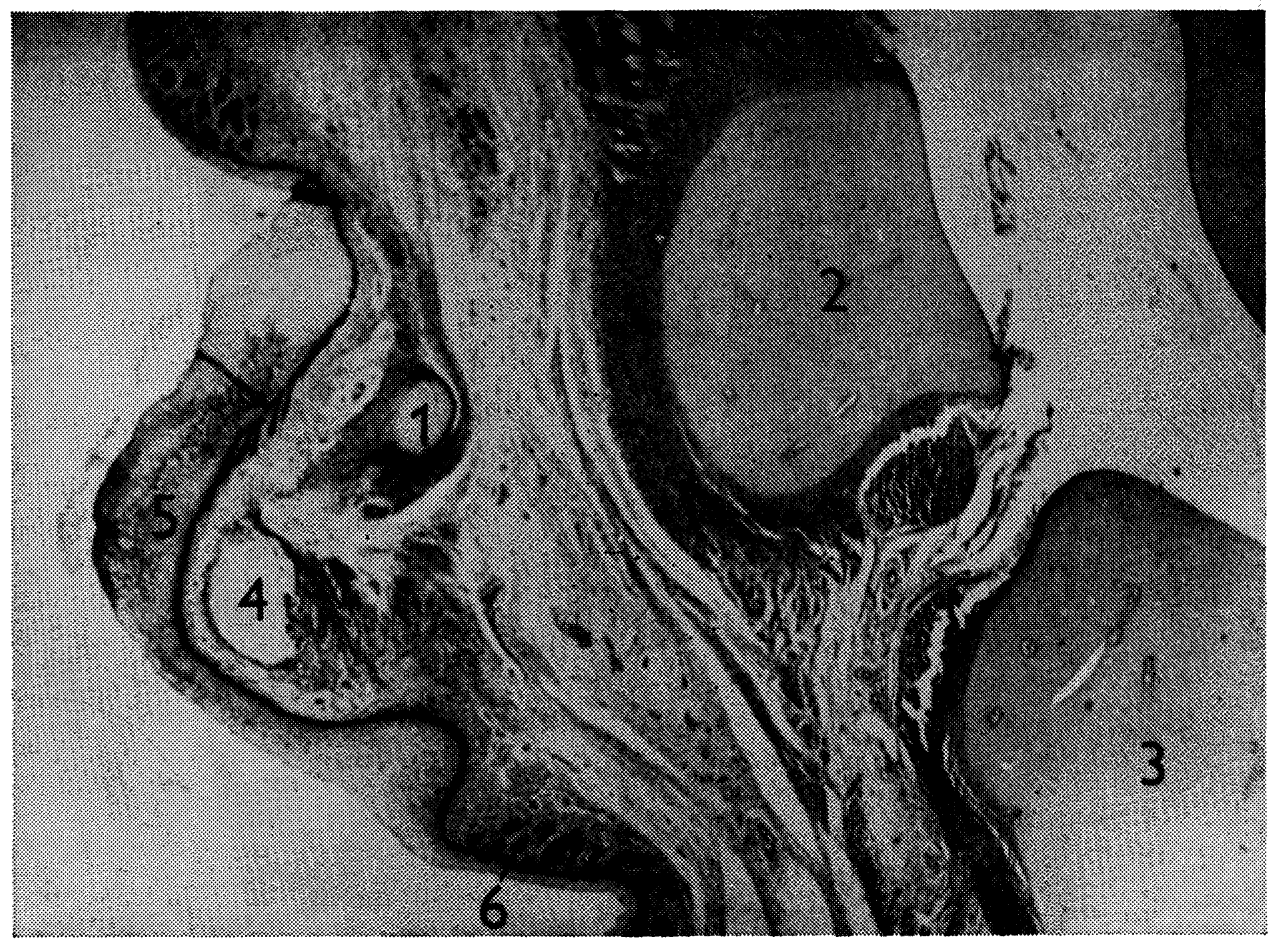


Plate VI.

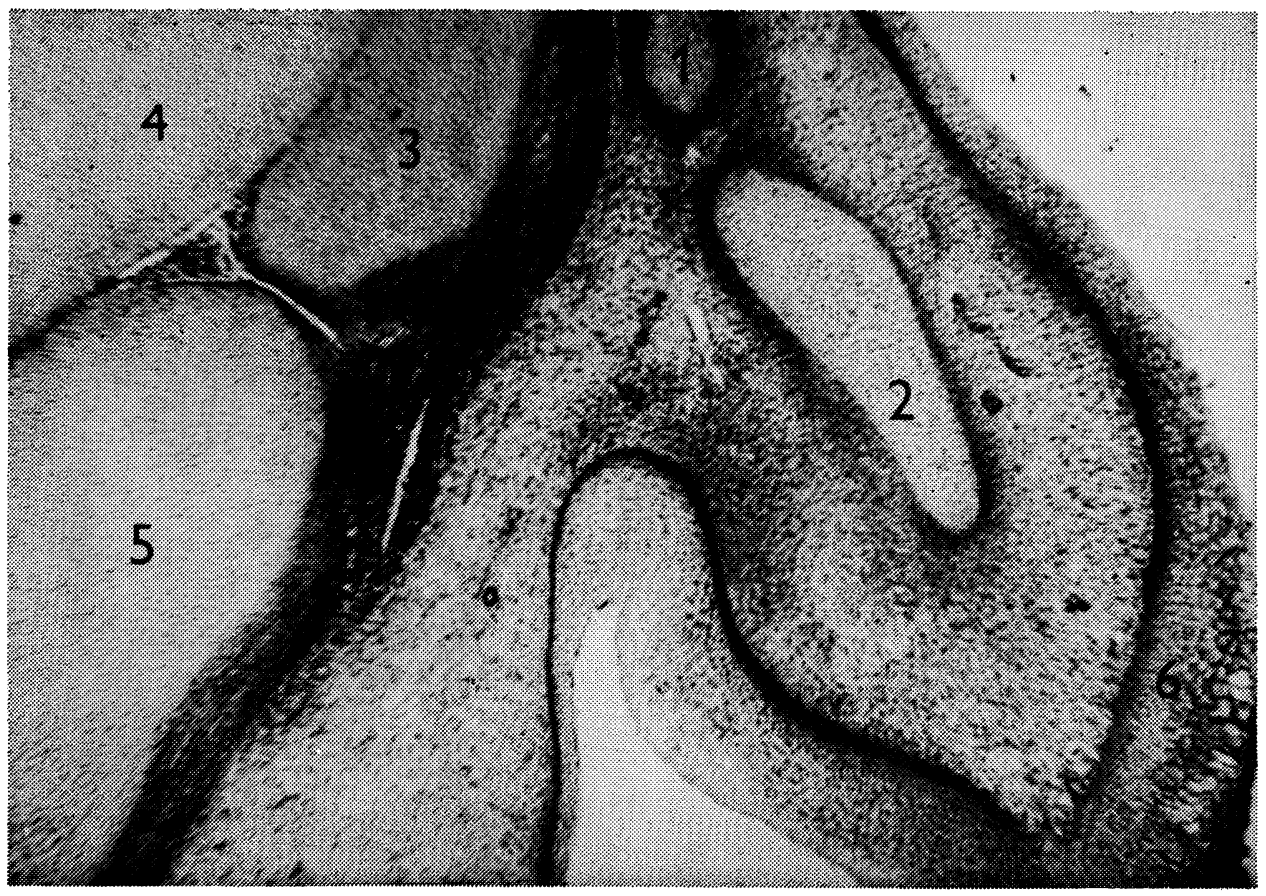

13

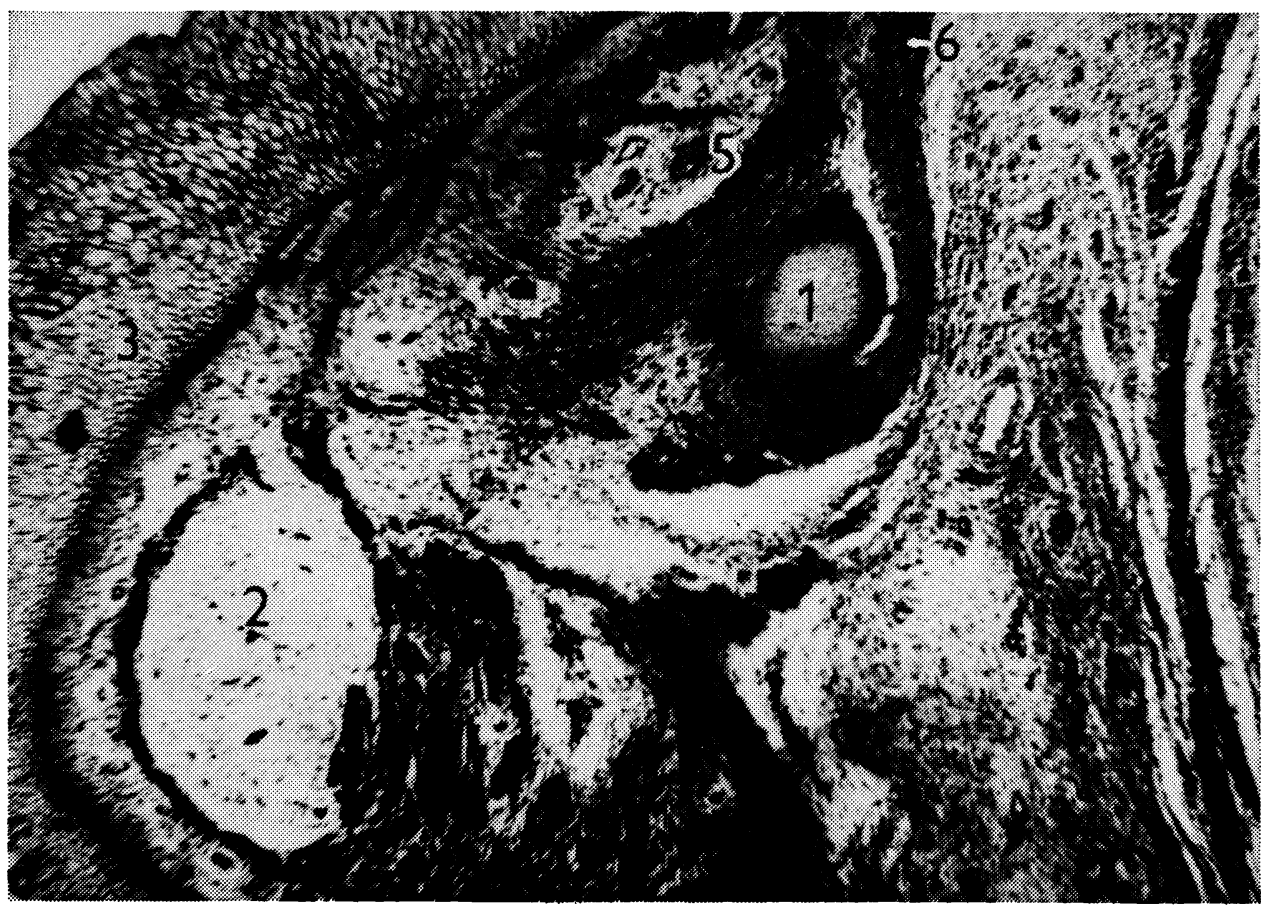


Plate VII.
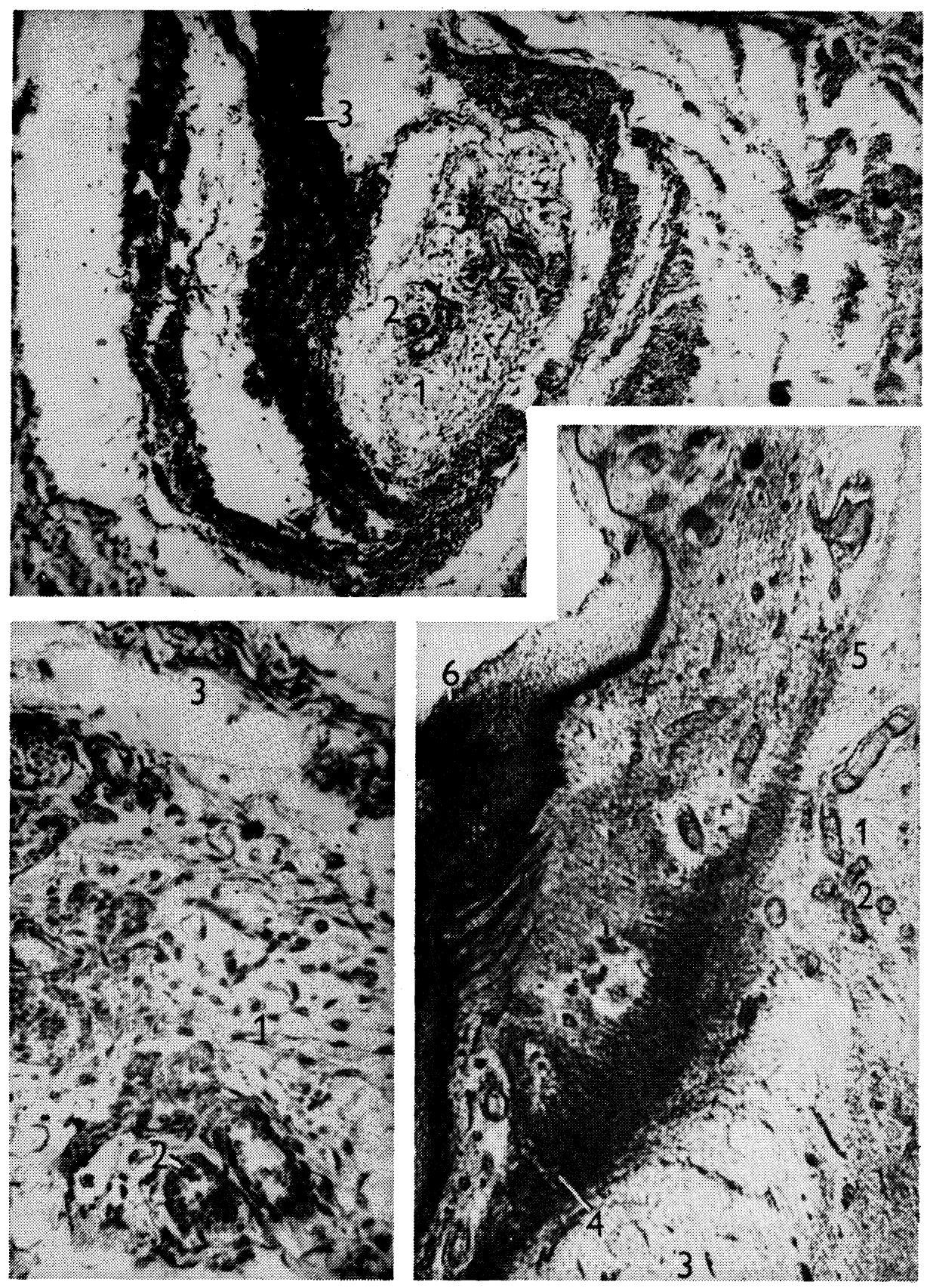
(.

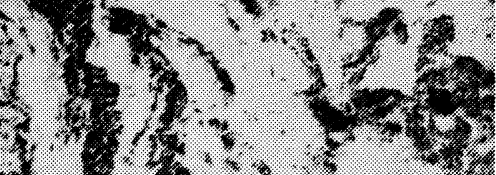
年: 
Plate VIII.
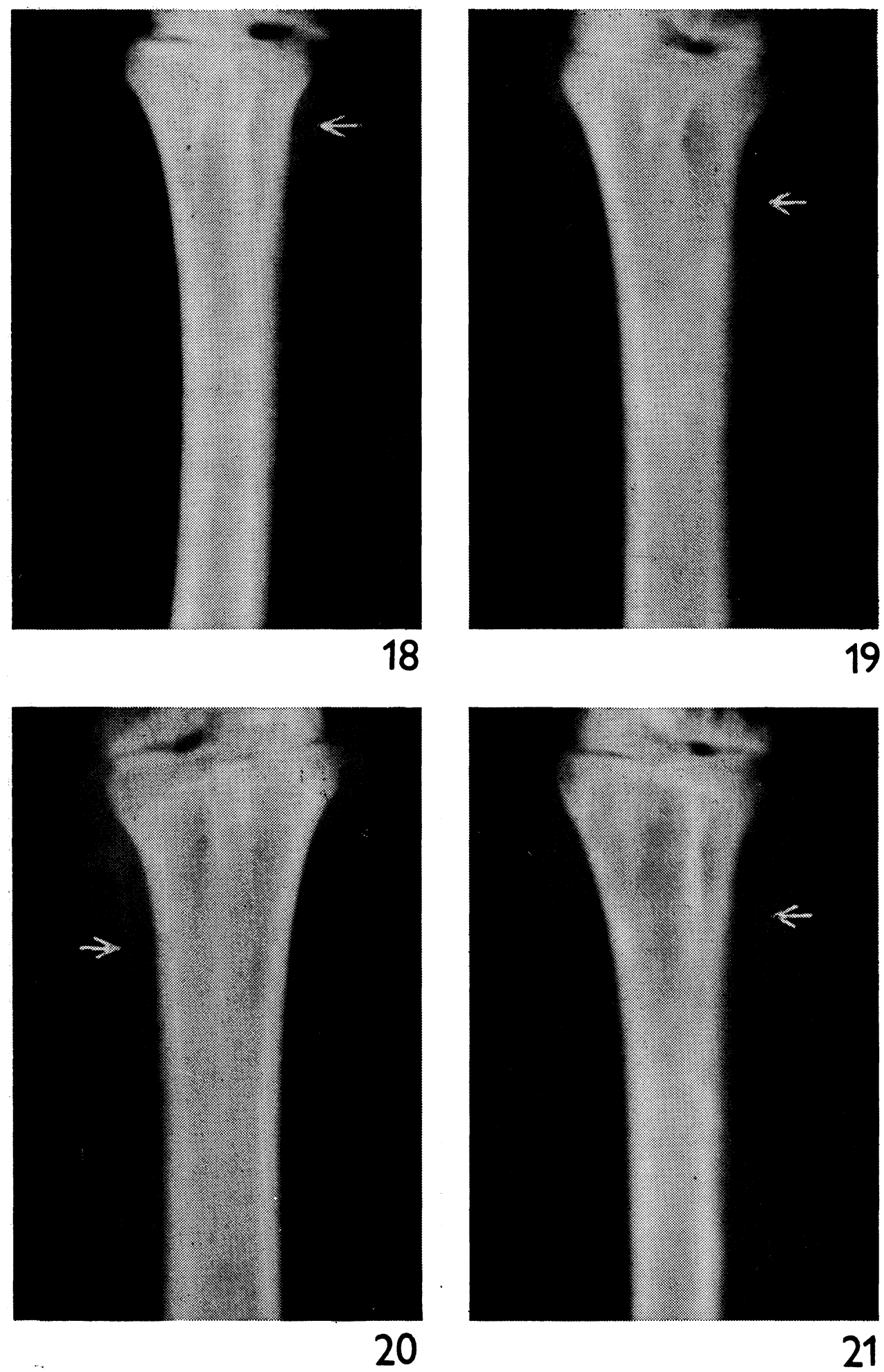
Plate IX.
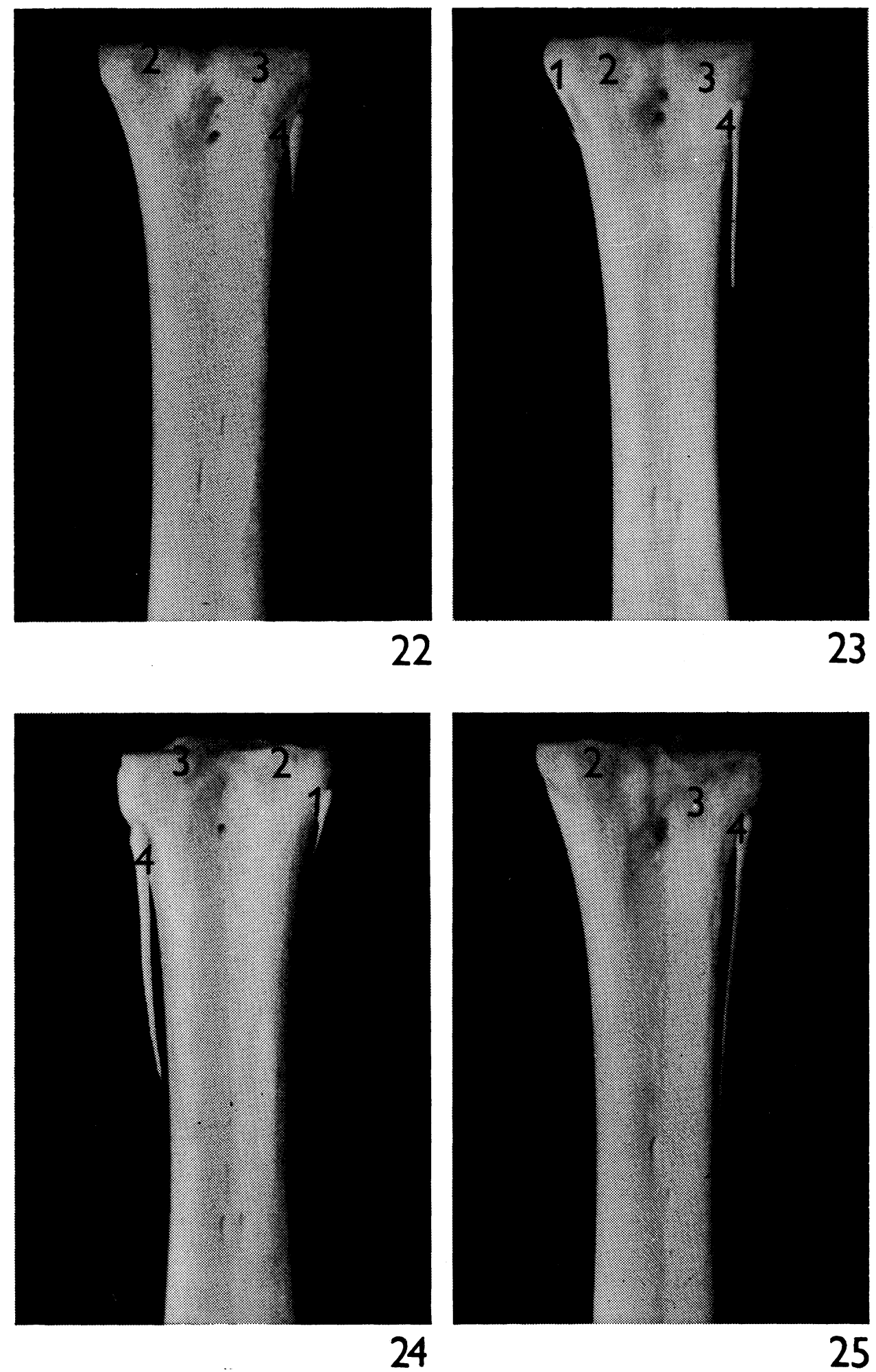
Plate X.

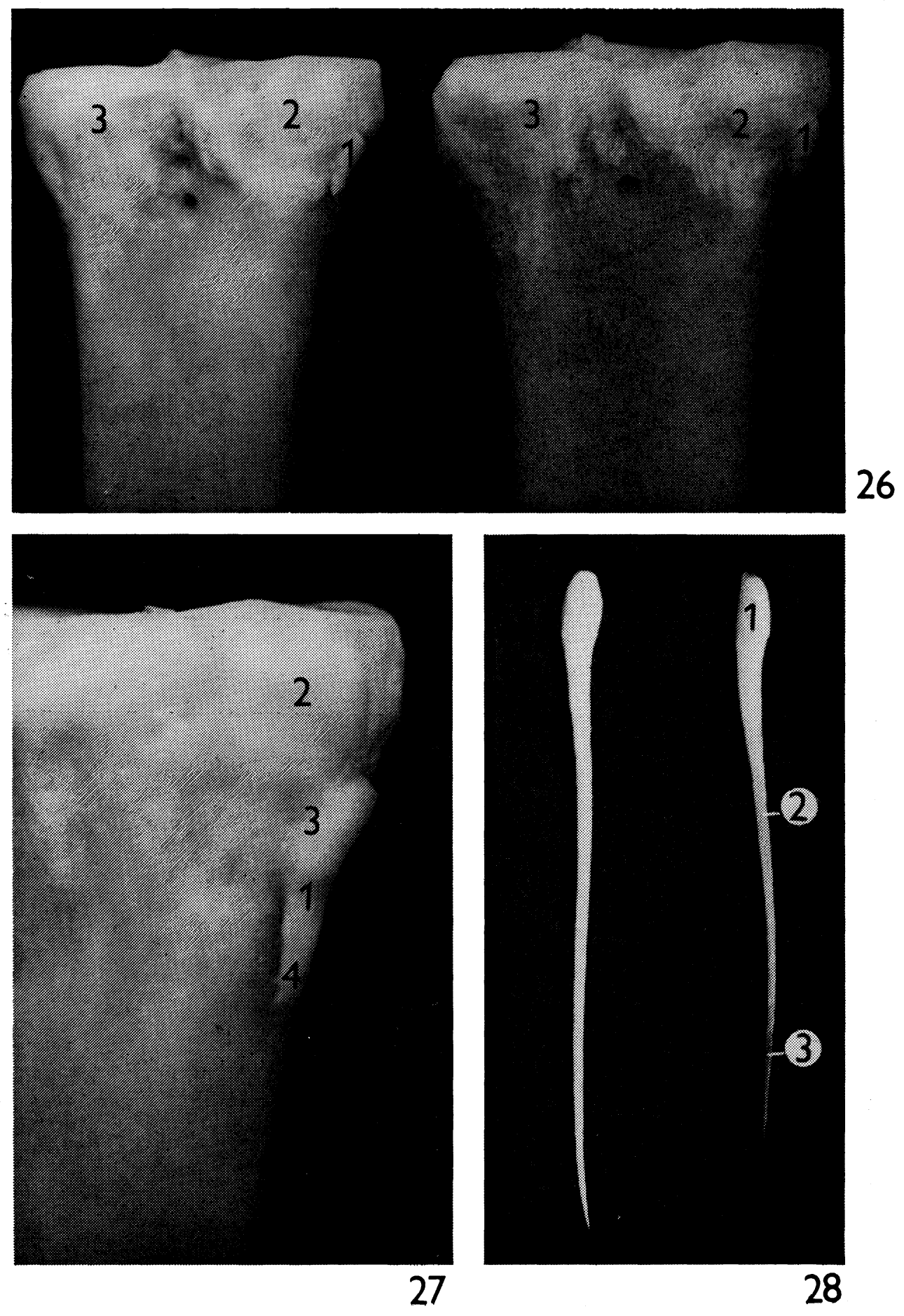

